\title{
Pengembangan Media Pembelajaran Aplikasi MaCa (Materi Pecahan) Berorientasi Teori Belajar Ausubel Muatan Matematika
}

\author{
Ni Luh Ade Rasvani ${ }^{*}$, I Gusti Agung Ayu Wulandari²
}

${ }^{12}$ Program Studi Guru Sekolah Dasar, Universitas Pendidikan Ganesha, Singaraja, Indonesia

\begin{tabular}{l} 
A R T I C L E I N F O \\
\hline Article history: \\
Received 1 Januari 2021 \\
Received in revised form \\
30 Januari 2021 \\
Accepted 1 Maret 2021 \\
Available online 8 April \\
2021 \\
\hline
\end{tabular}

Kata Kunci: aplikasi, materi, pecahan, ausubel

Keywords: application, fractional material, ausubel

\begin{abstract}
A B S T R A K
Pemanfaatan teknologi dibidang pendidikan belum sepenuhnya optimal sehingga mempengaruhi proses pelaksanaan pembelajaran yang berdampak pada kualitas pembelajaran. Penelitian ini bertujuan untuk menganalisis pengembangan media pembelajaran aplikasi $\mathrm{MaCa}$ (Materi Pecahan) berorientasi Teori Belajar Ausubel muatan matematika. Penelitian yang digunakan adalah jenis penelitian pengembangan dengan menggunakan model ADDIE. Subjek penelitian ini adalah validitas media pembelajaran aplikasi MaCa (Materi Pecahan) berorientasi Teori Belajar Ausubel muatan matematika. Metode pengumpulan data yang digunakan adalah metode non tes yang diberikan kepada tiga pakar ahli serta siswa. Instrumen yang digunakan yaitu berupa lembar angket validasi untuk mengetahui kelayakan aplikasi dan angket respon siswa untuk mengetahui kemenarikan aplikasi. Teknik analisis data yang digunakan adalah teknik analisis deskriptif kuantitatif. Hasil penelitian ini adalah menunjukkan persentase hasil dari validitas oleh ahli media $91,66 \%$, ahli desain $93,75 \%$, ahli isi mata pelajaran sebesar $87,5 \%$, dan respon siswa dari hasil uji coba produk perorangan
\end{abstract} sebesar $98,48 \%$ dan uji coba produk kelompok kecil 93,93\%. Simpulan penelitian ini adalah media pembelajaran aplikasi MaCa (Materi Pecahan) berorientasi Teori Belajar Ausubel muatan matematika dinyatakan sangat baik dan layak untuk dapat digunakan dalam proses pembelajaran. Implikasi penelitian ini adalah dapat membuat siswa lebih aktif dan kreatif sehingga dapat memudahkan proses pembelajaran serta mengoptimalkan pencapaian belajar siswa.

\begin{abstract}
A B S T R A C T
The use of technology in the field of education has not been fully optimal so that it affects the learning implementation process which has an impact on the quality of learning. This study aims to analyze the development of learning media for the application of $\mathrm{MaCa}$ (Fractional Material) oriented to Ausubel Learning Theory of mathematics content. The research used is a type of development research using the ADDIE model. The subject of this research is the validity of the learning media application MaCa (Fractional Material) oriented to Ausubel Learning Theory of mathematics content. The data collection method used is the non-test method given to three expert experts and students. The instrument used was in the form of a validation questionnaire sheet to determine the appropriateness of the application and a student response questionnaire to determine the attractiveness of the application. The data analysis technique used is quantitative descriptive analysis technique. The results of this study are that the percentage of the results of the validity by media experts is $91.66 \%$, design experts $93.75 \%$, subject content experts is $87.5 \%$, and student responses from the results of individual product trials are $98.48 \%$ and test results. try small group products $93.93 \%$. The conclusion of this research is the learning media application MaCa (Fractional Material) oriented to Ausubel Learning Theory, the mathematics content is stated to be very good and feasible to be used in the learning process. The implication of this research is that it can make students more active and creative so that it can facilitate the learning process and optimize student learning achievement.
\end{abstract}




\section{Pendahuluan}

Perkembangan teknologi saat ini memilki pengaruh yang signifikan pada semua aspek kehidupan manusia khususnya pada dunia pendidikan, salah satunya pemanfaatan hasil teknologi pada sarana penunjang proses belajar yaitu media pembelajaran. Guru dalam melaksanakan pembelajaran selain diharuskan dapat memahami hakekat materi yang akan diajarkan, guru juga dituntut untuk dapat memanfaatkan media pembelajaran secara kreatif agar tercapainya tujuan pembelajaran secara maksimal (Hasanah et al., 2018; Heru \& Yuliani, 2020; Pratiwi et al., 2017). Oleh karena itu dalam proses belajar mengajar seorang guru hendaknya terampil dalam memilih, menggunakan dan menyesuaikan media yang akan digunakan hingga dapat meningkatkan kualitas dan efektifitas pengajaran tersebut.

Pemanfaatan media oleh guru sebaiknya didasarkan pada desain atau rancangan pembelajaran yang akan dilaksanakan sehingga prinsip pemanfaatan perlu dikaitkan dengan kebutuhan dan karakteristik siswa. Kegiatan mengajar di kelas akan efektif bila seorang pendidik menggunakan media pembelajaran untuk menanamkan konsep kepada siswa (Firdaus et al., 2020; Herliana \& Anugraheni, 2020; Nomleni \& Manu, 2018). Oleh karena itu penting untuk melakukan pengembangan sebuah media pembelajaran yang dapat menunjang proses serta kualitas pembelajaran.

Berdasarkan hasil wawancara bersama narasumber yaitu guru wali kelas III SD N 3 Celuk yang menyatakan salah satu kendala dalam proses pembelajaran daring adalah terbatasnya sarana teknologi yang dimiliki oleh siswa karena masih menggunakan handphone atau laptop milik orang tua sehingga guru seringkali kesulitan untuk melakukan waktu belajar secara bersamaan dalam satu kelas. Seorang pendidik selain sebagai fasilitator dan pembimbing juga dituntut untuk dapat kreatif sehingga dalam pelaksanaan pembelajaran dapat berlangsung secara efektif sehingga berdampak pada pencapaian hasil belajar. Dalam proses pelaksanaan pembelajaran daring saat ini guru cenderung menggunakan diskusi melalui media aplikasi grup Whatsapp atau Google Conference sehingga kegiatan belajar lebih banyak dilakukan menggunakan video bersumber dari youtube tanpa memaksimalkan teknologi media pembelajaran sehingga seringkali video yang didapatkan memiliki kelemahan karena tidak sesuai dengan indikator yang telah disusun oleh guru. Permasalahan dari faktor kepemilikan fasilitas handphone atau laptop juga sangat berpengaruh. Dibutuhkannya sebuah media fleksibel dalam pemberian materi, memberikan pertanyaan dan lain sebagainya yang bersifat mandiri dan membuat pembelajaran lebih menarik. Salah satu solusi yang diberikan adalah pengembangan multimedia berupa aplikasi pembelajaran.

Perkembangan teknologi telah menciptakan bentuk media baru yaitu program multimedia. Program multimedia memuat isi dan materi pembelajaran secara konsisten dan memungkinkan siswa untuk mengakses materi setiap saat dan menjadi kendali penuh terhadap proses pembelajaran yang dilaksanakan. Proses pembelajaran yang baik haruslah memuat aspek interaktif, menyenangkan dan menantang serta memotivasi siswa (Akbar, 2016; Ashfahany et al., 2017; Yuniarni et al., 2020).

Program multimedia juga memiliki sifat interaktif karena diberikan feedback ketika mengoperasikannya yang akan berdampak pada aktifnya siswa dalam menggunakan program multimedia tersebut (Firdaus et al., 2020; Nopriyanti \& Sudira, 2015; Sari \& Sugiyarto, 2015). Penerapan teknologi khususnya program multimedia yang dapat diterapkan dalam proses pembelajaran salah satunya yaitu penggunaan sebuah aplikasi. Namun demikian, permasalahan seperti kurang cakapnya guru dalam penggunaan teknologi sampai pada fasilitas teknologi yang tidak dimanfaatkan secara optimal menjadi salah satu faktor yang menghambat perkembangan teknologi dalam dunia pendidikan khususnya di Indonesia. Apabila dimanfaatkan dengan baik, teknologi dalam dunia pendidikan dapat memudahkan proses pembelajaran dan mengoptimalkan pencapaian belajar siswa salah satunya yaitu mata pelajaran matematika.

Matematika merupakan proses berfikir yang berperan membantu dalam sarana menyelesaikan suatu persoalan (Amirulloh et al., 2019; Indriani, 2018; Pujianingtias et al., 2019). Tingkat kesulitan dalam mempelajari matematika akan terus bertambah seiring dengan meningkatnya perkembangan koginitif siswa oleh karena itu mata pelajaran matematika sering dianggap sulit oleh siswa, tak terkecuali untuk siswa sekolah dasar. Hal tersebut juga berlaku pada sulitnya siswa dalam memahami konsep materi pecahan. Kesulitan ini berawal dari kurangnya pemahaman konsep pecahan secara menyeluruh, padahal pemahaman konsep merupakan suatu dasar atau tonggak untuk keberhasilan 
mempelajari materi berikutnya. Adapun faktor yang mempengaruhi hal tersebut dapat berasal dari guru maupun sarana prasana yang tersedia di tempat belajar.

Dalam menyampaikan suatu konsep materi selain perlunya suatu penyesuaian gaya belajar anak, pemahaman materi akan lebih mudah dipahami jika dalam penyampaian materi dikaitkan dan dihubungkan dengan konsep yang sudah ada dalam struktur kognitif siswa (Awalia et al., 2019; Kurniawan, 2017; Laily et al., 2019). Jadi untuk membantu siswa memahami materi mengenai pecahan maka sangat diperlukan belajar bermakna dimana siswa tidak hanya sekedar menghafal konsep atau fakta tetapi merupakan kegiatan menghubungkan konsep-konsep untuk menghasilkan pemahaman yang utuh sehingga konsep yang dipelajari akan dipahami secara baik dan tidak mudah dilupakan.

Teori Ausubel yang menyebutkan dalam membantu siswa menanamkan pengetahuan baru dari suatu materi, sangat diperlukan konsep awal yang sudah dimiliki siswa yang berkaitan dengan konsep yang akan dipelajari sehingga sangat menentukan berhasil tidaknya suatu proses pembelajaran (Gazali, 2016; Kinasih \& Sinaga, 2020; Majdi, 2019). Hal tersebut akan cukup sulit untuk dibelajarkan apalagi jika tidak dibarengi dengan pemanfaatan teknologi secara efektif oleh guru ditambah dengan adanya kebijakan pemerintah untuk melaksanakan pembelajaran daring yang dituangkan dalam keputusan bersama antara menteri pendidikan dan menteri kebudayaan, menteri agama, menteri kesehatan, dan menteri dalam negeri Republik Indonesia yang salah satunya berisi mengenai pelaksanaan pembelajaran tahun ajaran 2020/2021 di satuan pendidikan yang berada di daerah zona kuning, oranye, dan merah dilarang melakukan proses pembelajaran tatap muka dan melanjutkan kegiatan belajar dari rumah (BDR) sehingga pembelajaran di tingkat sekolah dasar saat ini pelaksanaannya menggunakan sistem pembelajaran daring.

Penggunaan media dalam proses pembelajaran matematika yang efektif dan efisien diharapkan mampu membentuk stimulus-stimulus yang direspon melalui pola pikir peserta didik dalam menunjang tercapainya tujuan pembelajaran (Fais et al., 2019; Pujianingtias et al., 2019; Wicaksana, 2017). Oleh karena itu untuk memudahkan penyampaian pembelajaran bermakna dalam belajar pecahan di tingkat sekolah dasar dalam situasi belajar dari rumah dan pentingnya pemanfaatan teknologi dalam proses pembelajaran, jadi pada penelitian ini dikembangkan sebuah media pembelajaran matematika yang menggunakan teknologi sebagai dasar pengembangannya yaitu pengembangan aplikasi pecahan berorientasi teori belajar Ausubel.

Aplikasi pecahan berorientasi teori belajar Ausubel yaitu sebuah media pembelajaran berupa program multimedia yaitu aplikasi yang memuat unsur teks, video, visual dan animasi serta bersifat interaktivitas dengan proses penggunaan media pembelajaran oleh siswa memanfaatkan perkembangan teknologi yaitu handphone berbasis android. Penggunaan handphone berbasis android dikarenakan sifatnya yang open source sehingga memudahkan pengguna dalam menggunakannya (Hardinata et al., 2018; Wicaksono et al., 2020; Yektyastuti \& Ikhsan, 2016).

Penelitian ini didukung dengan beberapa penelitian sebelumnya yang relevan dengan penelitian ini seperti, pertama penelitian yang dilaksanakan oleh (Mbagho \& Tupen, 2020), yang memperoleh hasil yaitu pembelajaran yang realistik dapat meningkatkan hasil belajar matematika pada materi operasi bilangan pecahan. Kedua, penelitian yang dilaksanakan oleh (Gazali, 2016), yang memperoleh hasil yaitu bahan ajar matematika berdasarkan Teori Belajar Ausubel dinyatakan valid dan layan digunakan didalam pembelajaran. memperoleh hasil yaitu. Ketiga, penelitian yang dilaksanakan oleh (Pujianingtias et al., 2019), yang memperoleh hasil yaitu media majamat pada materi pecahan pada mata pelajaran matematika dinyatakan valid dan dapat digunakan didalam proses pembelajaran.

Tujuan dilaksanakannya penelitian pengembangan ini adalah untuk menganalisis pengembangan media pembelajaran aplikasi MaCa (Materi Pecahan) berorientasi Teori Belajar Ausubel muatan matematika di SD Negeri 3 Celuk.

\section{Metode}

Jenis penelitian yang digunakan adalah penelitian pengembangan atau research \& development $(R \& D)$, yang dilaksanakan di SD Negeri 3 Celuk. Pengembangan media pembelajaran dalam penelitian ini dilakukan berdasarkan prosedur penelitian \& pengembangan menggunakan model ADDIE yang terdiri dari tahapan Analisis (Analysis), Desain (Design), Pengembangan (Development), Implementasi (Implementation), dan Evaluasi (Evaluation). Model ADDIE sangat relevan untuk digunakan karena 
memiliki tingkat fleksibilitas yang tinggi sehingga dapat disesuaikan dengan kebutuhan dalam menjawab suatu permasalahan.

Subjek penelitian ini adalah validitas media pembelajaran aplikasi MaCa (Materi Pecahan) berorientasi Teori Belajar Ausubel muatan matematika. Penelitian pengembangan tidak dipergunakan menguji sebuah teori melainkan untuk menguji atau menyempurnakan suatu produk. Penyempurnaan suatu produk bertujuan untuk meningkatkan nilai efektifitas dan efisiensi dari suatu produk yang telah digunakan sebelumnya.

Metode pengumpulan data yang digunakan untuk memperoleh data dan informasi dari penelitian ini menggunakan metode non tes berupa lembar kuesioner atau angket yang dipergunakan untuk mengetahui penilaian responden/uji kelayakan (ahli materi, ahli media), validasi terhadap media pembelajaran yang dikembangkan serta siswa sebagai subjek uji coba produk yang meliputi uji coba perorangan dan uji coba kelompok oleh siswa. Angket dalam penelitian ini disusun berdasarkan aspek dan kriteria yang sesuai dengan spesifikasi produk yang didasarkan pada beberapa kriteria yaitu sangat setuju (SS), setuju (S), tidak setuju (TS), dan sangat tidak setuju (STS) yang selanjutnya dikonversi menggunakan skala likert empat.

Hasil skor dari data angket yang diperoleh dianalisis menggunakan teknik analisis deskriptif kuantitatif dengan membandingkan jumlah skor responden $\left(\sum \mathrm{R}\right)$ dengan jumlah skor ideal $(\mathrm{N})$ yang selanjutnya kualifikasi produk ditentukan menggunakan kriteria kelayakan media untuk dapat mengetahui tingkat pencapaian kelayakan media pembelajaran yang dikembangkan.

\section{Hasil dan Pembahasan}

Pengembangan media pembelajaran berupa Aplikasi Pecahan untuk siswa sekolah dasar kelas III dengan materi pecahan. Penelitian ini dilaksanakan di SD N 3 Celuk yang dilaksanakan melalui beberapa tahapan yang dilakukan dengan menggunakan model ADDIE yaitu Analisis (Analysis), Desain (Design), Pengembangan (Development), Implementasi (Implementation), dan Evaluasi (Evaluation).

Pada tahap pertama dilaksanakan analisis masalah. Observasi serta wawancara dilakukan untuk menganalisis kesenjangan yang terjadi ditempat penelitian, menganalisis kebutuhan serta penentuan kompetensi dasar dan indikator. Sesuai dengan hasil observasi dan wawancara bersama narasumber yaitu guru wali kelas III SD N 3 Celuk menyatakan salah satu kendala dalam proses pembelajaran daring adalah terbatasnya sarana teknologi yang dimiliki oleh siswa karena masih menggunakan handphone atau laptop milik orang tua sehingga guru seringkali kesulitan untuk melakukan waktu belajar secara bersamaan dalam satu kelas yang menyebabkan kegiatan diskusi belum dapat dilaksanakan secara optimal. Hal tersebut sejalan dengan hasil survei kepada siswa, yang menyatakan bahwa pada masa pandemi ini beberapa siswa mengalami kesulitan dalam memahami suatu konsep materi, terutama dalam mata pelajaran matematika. Pada tahap analisis juga dilakukan pemilihan materi pembelajaran yang relevan dengan produk yang dikembangkan dan selanjutnya dilakukan identifikasi kompetensi dasar serta indicator. Materi yang dibuatkan pada aplikasi yaitu materi pecahan tema 2 (menyayangi tumbuhan \& hewan), subtema 4 (menyayangi hewan) pembelajaran 1.

Tahapan kedua yaitu tahap desain (design). Pada tahap ini ide serta konsep pada produk dikembangkan. Tahap ini meliputi pengumpulan data, pembuatan bagan alur dan sketsa. Pengumpulan data berupa gambar teks, audio dan materi yang dibutuhkan dalam pengembangan produk. Selanjutnya diagram alur atau flowachart dipergunakan pengembang dalam mengerti maksud langkah-langkah pengoperasian programnya.

Tahapan ketiga yaitu tahap pengembangan. Pada tahap pengembangan semua hal yang sebelumnya telah dirancang mulai dikerjakan. Produk yang siap diujicobakan merupakan hasil akhir dari tahap pengembangan ini. Berikut kegiatan pada tahap development hingga menjadi sebuah produk: (1) mendesain logo, proses pembuatan logo dalam aplikasi yang dikembangkan didesain menggunakan aplikasi PixelLab, logo aplikasi dibuat semenarik mungkin karena akan ditampilkan pada layar smartphone siswa; (2) pembuatan interface aplikasi, proses pembuatan interface atau tampilan layar aplikasi menggunakan Microsoft Power Point 2016; (3) menginput isi materi, isi materi yang diinput dalam aplikasi terdiri dari teks materi, gambar pendukung serta video pembelajaran yang didesain agar menjadi lebih menarik berupa teks yang dapat bergerak serta audio dan musik latar belakang yang sesuai; (4) menambahkan interaktivitas pada interface, penambahan interaktivitas 
pada ikon-ikon tombol di Microsoft Power Point 2016 dilakukan pada bagian hyperlink; (5) pembuatan soal latihan, kolom identitas pengguna, petunjuk teknis dalam menjawab, serta penambahan feedback berupa kalimat reward bagi siswa dalam menjawab soal secara benar maupun salah, proses pembuatan dilakukan menggunakan aplikasi iSpring Suite 10 yang terkoneksi dengan aplikasi Microsoft Power Point 2016, lama pengerjaan soal diatur menjadi 10 menit per soal, selanjutnya siswa yang telah menjawab seluruh soal dan mengirim hasil jawaban akan langsung mendapatkan skor atau nilai; (6) mengubah data Power Point menjadi HTML 5 dengan iSpring Suite 10, pada tahap ini data powerpoint maupun latihan soal diubah menjadi berbentuk HTML 5 dengan menggunakan iSpring Suite 10; (7) mengubah data HTML 5 menjadi berbasis aplikasi, data mental HTML 5 diubah menjadi aplikasi menggunakan Apkbuilder Pro v3.4 agar dapat digunakan pada system berbasis android; (8) Instalasi aplikasi, instalasi aplikasi bisa dilakukan dengan mengaploud data aplikasi ke google drive yang selanjutnya link data tersebut dapat dibuka melalui handphone dan langsung diinstal, penginstalan aplikasi bertujuan untuk dapat mengetahui apakah aplikasi sudah dapat dioperasikan dengan baik serta mengecek interaktivitas tombol yang sudah dibuat; (9) Validitas produk, pada tahap ini disusun angket untuk dapat memvalidasi produk sesuai dengan kriteria atau aspek yang diukur, pada tahap ini pula hasil pengembangan media pembelajaran berupa aplikasi di validasi oleh validator untuk mengetahui kualitas produk yang dikembangkan. Validasi produk dilakukan oleh para ahli diantaranya ahli isi pembelajaran, ahli media pembelajaran dan ahli desain pembelajaran. Produk media yang dihasilkan dapat dilihat pada Gambar 1 dan Gambar 2.

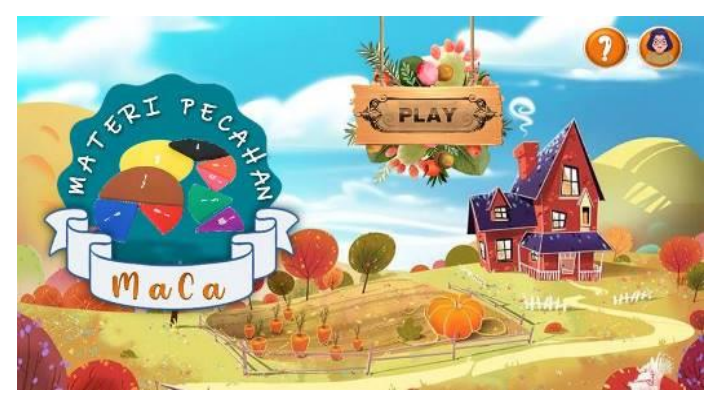

Gambar 1. Logo media aplikasi MaCa

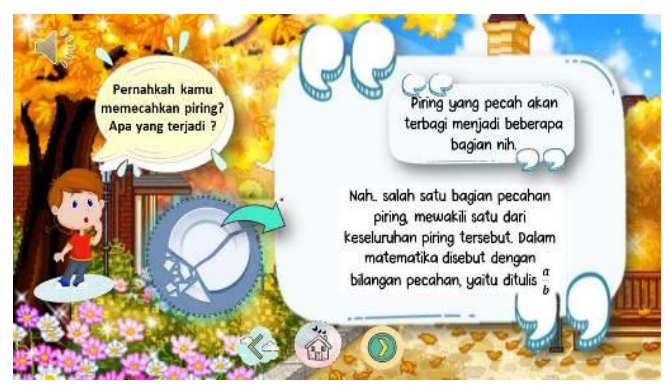

Gambar 2. Isi media aplikasi MaCa

Tahapan keempat adalah tahap implementasi. Tahap implementasi dilakukan untuk mendapatkan respon pengguna terhadap produk yang telah dibuat. Pada tahap ini dilakukan validasi produk oleh pakar ahli diantaranya ahli isi mata pelajaran, ahli media pembelajaran dan ahli desain pembelajaran. Pada tahap produk direvisi sesuai dengan masukan beserta saran dari pakar ahli. Setelah hasil validasi telah mendapat kriteria baik maka produk selanjutnya di uji cobakan pada uji perorangan dan uji kelompok kecil. Uji lapangan serta uji efektivitas tidak dapat dilaksanakan karena keadaan dan situasi yang tidak memungkinkan ditengah situasi pembelajaran secara daring.

Tahapan terakhir yaitu tahap evaluasi. Pada tahap ini dilakukan evaluasi secara keseluruhan. Evaluasi yang dilakukan berupa evaluasi formatif untuk memberikan penilaian terhadap produk yang divalidasi oleh para ahli. Adapun hasil validasi dan uji coba produk dapat dilihat pada Tabel 1.

Tabel 1. Hasil Validasi Produk

\begin{tabular}{ccc}
\hline Subjek Uji Coba & Hasil Validitas (\%) & Kualifikasi Persentase \\
\hline Ahli Isi Mata Pelajaran & 87,5 & Baik \\
Ahli Media Pembelajaran & 91,66 & Sangat Baik \\
Ahli Desain Pembelajaran & 93,75 & Sangat Baik \\
Uji Coba Perorangan & 90,25 & Sangat Baik \\
Uji Coba Kelompok Kecil & 90,15 & Sangat Baik \\
\hline
\end{tabular}

Hasil validasi produk oleh pakar ahli yang telah dijabarkan pada tabel 1 menunjukan bahwa media pembelajaran aplikasi MaCa (materi pecahan) menurut pakar ahli termasuk berkualifikasi baik sehingga layak untuk dapat di uji cobakan kepada siswa. Adapun hasil yang diperoleh dari uji coba produk yaitu uji coba perorangan sebesar 90,25 \% dan uji coba kelompok sebesar 90,15 \% sehingga 
produk sangat baik dan tepat untuk dapat digunakan sebagai media pembelajaran khususnya pada pembelajaran materi pecahan.

Program multimedia juga memiliki sifat interaktif karena diberikan feedback ketika mengoperasikannya yang akan berdampak pada aktifnya siswa dalam menggunakan program multimedia tersebut (Firdaus et al., 2020; Nopriyanti \& Sudira, 2015; Sari \& Sugiyarto, 2015). Penerapan teknologi khususnya program multimedia yang dapat diterapkan dalam proses pembelajaran salah satunya yaitu penggunaan sebuah aplikasi. Apabila dimanfaatkan dengan baik, teknologi dalam dunia pendidikan dapat memudahkan proses pembelajaran dan mengoptimalkan pencapaian belajar siswa salah satunya yaitu mata pelajaran Matematika.

Matematika merupakan proses berfikir yang berperan membantu dalam sarana menyelesaikan suatu persoalan (Amirulloh et al., 2019; Indriani, 2018; Pujianingtias et al., 2019). Tingkat kesulitan dalam mempelajari matematika akan terus bertambah seiring dengan meningkatnya perkembangan koginitif siswa oleh karena itu mata pelajaran matematika sering dianggap sulit oleh siswa, tak terkecuali untuk siswa sekolah dasar. Hal tersebut juga berlaku pada sulitnya siswa dalam memahami konsep materi pecahan. Kesulitan ini berawal dari kurangnya pemahaman konsep pecahan secara menyeluruh, padahal pemahaman konsep merupakan suatu dasar atau tonggak untuk keberhasilan mempelajari materi berikutnya. Adapun faktor yang mempengaruhi hal tersebut dapat berasal dari guru maupun sarana prasana yang tersedia di tempat belajar.

Dalam menyampaikan suatu konsep materi selain perlunya suatu penyesuaian gaya belajar anak, pemahaman materi akan lebih mudah dipahami jika dalam penyampaian materi dikaitkan dan dihubungkan dengan konsep yang sudah ada dalam struktur kognitif siswa (Awalia et al., 2019; Kurniawan, 2017; Laily et al., 2019). Jadi untuk membantu siswa memahami materi mengenai pecahan maka sangat diperlukan belajar bermakna, siswa tidak hanya sekedar menghafal konsep atau fakta tetapi merupakan kegiatan menghubungkan konsep-konsep untuk menghasilkan pemahaman yang utuh sehingga konsep yang dipelajari akan dipahami secara baik dan tidak mudah dilupakan.

Teori Ausubel yang menyebutkan dalam membantu siswa menanamkan pengetahuan baru dari suatu materi, sangat diperlukan konsep awal yang sudah dimiliki siswa yang berkaitan dengan konsep yang akan dipelajari sehingga sangat menentukan berhasil tidaknya suatu proses pembelajaran (Gazali, 2016; Kinasih \& Sinaga, 2020; Majdi, 2019). Untuk memberikan pemahaman konsep diperlukan media yang efektif dan efisien membantu siswa didalam pelaksanaan pembelajaran.

Penggunaan media dalam proses pembelajaran matematika yang efektif dan efisien diharapkan mampu membentuk stimulus-stimulus yang direspon melalui pola pikir peserta didik dalam menunjang tercapainya tujuan pembelajaran (Fais et al., 2019; Pujianingtias et al., 2019; Wicaksana, 2017). Oleh karena itu untuk memudahkan penyampaian pembelajaran bermakna dalam belajar pecahan di tingkat sekolah dasar dalam situasi belajar dari rumah dan pentingnya pemanfaatan teknologi dalam proses pembelajaran, jadi pada penelitian ini dikembangkan sebuah media pembelajaran matematika yang menggunakan teknologi sebagai dasar pengembangannya yaitu pengembangan aplikasi pecahan berorientasi teori belajar Ausubel.

Aplikasi pecahan berorientasi teori belajar Ausubel yaitu sebuah media pembelajaran berupa program multimedia yaitu aplikasi yang memuat unsur teks, video, visual dan animasi serta bersifat interaktivitas dengan proses penggunaan media pembelajaran oleh siswa memanfaatkan perkembangan teknologi yaitu handphone berbasis android. Penggunaan handphone berbasis android dikarenakan sifatnya yang open source sehingga memudahkan pengguna dalam menggunakannya (Hardinata et al., 2018; Wicaksono et al., 2020; Yektyastuti \& Ikhsan, 2016).

Penelitian ini didukung dengan beberapa penelitian sebelumnya yang relevan dengan penelitian ini seperti, pertama penelitian yang dilaksanakan oleh (Mbagho \& Tupen, 2020), yang memperoleh hasil yaitu pembelajaran yang realistik dapat meningkatkan hasil belajar matematika pada materi operasi bilangan pecahan. Kedua, penelitian yang dilaksanakan oleh (Gazali, 2016), yang memperoleh hasil yaitu bahan ajar matematika berdasarkan Teori Belajar Ausubel dinyatakan valid dan layak digunakan di dalam pembelajaran. Ketiga, penelitian yang dilaksanakan oleh (Pujianingtias et al., 2019), yang memperoleh hasil yaitu media majamat pada materi pecahan pada mata pelajaran matematika dinyatakan valid dan dapat digunakan di dalam proses pembelajaran.

Implikasi pelaksanaan penelitian pengembangan media pembelajaran aplikasi MaCa (Materi Pecahan) berorientasi Teori Belajar Ausubel muatan matematika adalah dapat membuat siswa lebih 
aktif dan kreatif sehingga dapat memudahkan proses pembelajaran serta mengoptimalkan pencapaian belajar siswa.

\section{Simpulan}

Simpulan dari pelaksanaan penelitian pengembangan ini adalah media pembelajaran aplikasi MaCa (Materi Pecahan) berorientasi Teori Belajar Ausubel muatan matematika dinyatakan sangat baik dan layak untuk dapat digunakan dalam proses pembelajaran. Implikasi penelitian ini adalah dapat membuat siswa lebih aktif dan kreatif sehingga dapat memudahkan proses pembelajaran serta mengoptimalkan pencapaian belajar siswa.

\section{Daftar Pustaka}

Akbar, T. N. (2016). Pengembangan Multimedia Interaktif IPA Berorientasi Guided Inquiry pada Materi Sstem Pernapasan Manusia Kelas V SDN Kebonsari 3 Malang. Jurnal Pendidikan: Teori, Penelitian, Dan Pengembangan, 1(6), 1120-1126. https://doi.org/10.17977/jp.v1i6.6456

Amirulloh, T. R. A., Risnasari, M., \& Ningsih, P. R. (2019). Pengembangan Game Edukasi Matematika (Operasi Bilangan Pecahan) Berbasis Android Untuk Sekolah Dasar. Jurnal Ilmiah Edutic, 5(2), 115-123. https://doi.org/10.21107/edutic.v5i2.5355

Ashfahany, F. A., Adi, S., \& Hariyanto, E. (2017). Bahan Ajar Mata Pelajaran Pendidikan Jasmani Olahraga dan Kesehatan Dalam Bentuk Multimedia Interaktif Untuk Siswa Kelas VII. Jurnal Pendidikan: Teori, Penelitian, Dan Pengembangan, 2(2), 261-267. https://doi.org/10.17977/jp.v2i2.8540

Awalia, I., Pamungkas, A. S., \& Alamsyah, T. P. (2019). Pengembangan Media Pembelajaran Animasi Powtoon pada Mata Pelajaran Matematika di Kelas IV SD. Kreano, Jurnal Matematika KreatifInovatif, 10(1), 49-56. https://doi.org/10.15294/kreano.v10i1.18534

Fais, M. Z., Listyarini, I., \& Tsalatsa, A. N. (2019). Pengembangan Media Papin dan Koja (Papan Pintar dan Kotak Ajaib) Sebagai Media Pembelajaran Matematika. Jurnal Penelitian Dan Pengembangan Pendidikan, 3(1), 26-30. https://doi.org/10.23887/jppp.v3i1.17097

Firdaus, F. Z., Suryanti, S., \& Azizah, U. (2020). Pengembangan Multimedia Interaktif Berbasis Pendekatan SETS Untuk Meningkatkan Kemampuan Berpikir Kritis Siswa Sekolah Dasar. Jurnal Basicedu, 4(3), 681-689. https://doi.org/10.31004/basicedu.v4i3.417

Gazali, R. Y. (2016). Pengembangan bahan ajar matematika untuk siswa SMP berdasarkan teori belajar ausubel. Pythagoras: Jurnal Pendidikan Matematika, 11(2), 182-192. https://doi.org/10.21831/pg.v11i2.10644

Hardinata, R., Murwitaningsih, S., \& Amirullah, G. (2018). Pengembangan Mobile Learning Sistem Koordinasi Berbasis Android. Bioeduscience, 2(1), 53-58. https://doi.org/10.29405/j.bes/5358121334

Hasanah, I., Sarwanto, S., \& Masykuri, M. (2018). Pengembangan Modul Suhu dan Kalor Berbasis Project Based Learning untuk Meningkatkan Keterampilan Proses Sains dan Kemampuan Berpikir Kritis Siswa SMA/MA. Jurnal Pendidikan (Teori Dan Praktik), 3(1), 38-44. https://doi.org/10.26740/jp.v3n1.p38-44

Herliana, S., \& Anugraheni, I. (2020). Pengembangan Media Pembelajaran Kereta Membaca Berbasis Kontekstual Learning Siswa Sekolah Dasar. Jurnal Basicedu, 4(2), 314-326. https://doi.org/10.31004/basicedu.v4i2.346

Heru, H., \& Yuliani, R. E. (2020). Pelatihan Pengembangan Bahan Ajar Multimedia Pembelajaran Interaktif Berbasis Pendekatan Saintifik Menggunakan Metode Blended Learning bagi Guru SMP/MTs Muhammadiyah Palembang. Jurnal Pengabdian Pada Masyarakat, 5(1), 35-44. https://doi.org/10.30653/002.202051.279

Indriani, A. (2018). Penggunaan Blok Pecahan Pada Materi Pecahan Sekolah Dasar. Jurnal Ilmiah 
Pendidikan Matematika Volume, 3(1), 11-16. https://doi.org/10.26877/jipmat.v3i1.2418

Kinasih, S., \& Sinaga, K. (2020). Kajian Penerapan Teori Pembelajaran Bermakna Ausubel Berdasarkan Perspektif Alkitabiah Pada Materi Hidrokarbon [A Study On The Application Of Ausubel's Meaningful Learning Theory On Hydrocarbon Chemical Learning Based On A Biblical Perspective]. Polyglot: Jurnal Ilmiah, 16(2), 141-153. https://doi.org/10.19166/pji.v16i2.2128

Kurniawan, D. T. (2017). Penggunaan Model PjBL Untuk Meningkatkan Kreativitas Mahasiswa Dalam Membuat Media Pembelajaran Matematika. Kalamatika: Jurnal Pendidikan Matematika, 2(2), 207. https://doi.org/10.22236/kalamatika.vol2no2.2017pp207-220

Laily, A., Jalal, F., \& Karnadi, K. (2019). Peningkatan Kemampuan Konsep Matematika Awal Anak Usia 4-5 Tahun melalui Media Papan Semat. Jurnal Obsesi : Jurnal Pendidikan Anak Usia Dini, 3(2), 396-403. https://doi.org/10.31004/obsesi.v3i2.214

Majdi, M. (2019). Analisis Teori Ausubel Pada Penerapan Model Realistic Mathematics Education Dalam Pembelajaran Matematika. Al-Mudarris, 2(1), 104-120. https://doi.org/10.32478/almudarris.v2i1.213

Mbagho, H. M., \& Tupen, S. N. (2020). Pembelajaran Matematika Realistik dalam Meningkatkan Hasil Belajar Matematika Materi Operasi Bilangan Pecahan. Jurnal Basicedu, 5(1), 121-132. https://doi.org/10.31004/basicedu.v5i1.632

Nomleni, F. T., \& Manu, T. S. N. (2018). Pengembangan Media Audio Visual dan Alat Peraga dalam Meningkatkan Pemahaman Konsep dan Pemecahan Masalah. Scholaria: Jurnal Pendidikan Dan Kebudayaan, 8(3), 219-230. https://doi.org/10.24246/j.js.2018.v8.i3.p219-230

Nopriyanti, N., \& Sudira, P. (2015). Pengembangan Multimedia Pembelajaran Interaktif Kompetensi Dasar Pemasangan Sistem Penerangan dan wiring kelistrikan di SMK. Jurnal Pendidikan Vokasi, 5(2), 222-235. https://doi.org/10.21831/jpv.v5i2.6416

Pratiwi, P. H., Hidayah, N., \& Martiana, A. (2017). Pengembangan Modul Mata Kuliah Penilaian Pembelajaran Sosiologi Berorientasi Hots. Jurnal Cakrawala Pendidikan, 36(2), 201-209. https://doi.org/10.21831/cp.v36i2.13123

Pujianingtias, E. N., Saputra, H. J., \& Muhajir. (2019). Pengembangan Media Majamat pada Materi Pecahan Pada Mata Pelajaran Matematika. Jurnal Penelitian Dan Pengembangan Pendidikan, 3(3), 257-263. https://doi.org/10.23887/jppp.v3i3.19261

Sari, D. S., \& Sugiyarto, K. H. (2015). Pengembangan Multimedia Berbasis Masalah Untuk Meningkatkan Motivasi Belajar Dan Kemampuan Berpikir Kritis Siswa. Jurnal Inovasi Pendidikan IPA, 1(2), 153-166. https://doi.org/10.21831/jipi.v1i2.7501

Wicaksana, N. (2017). Pengaruh Model Pembelajaran Open Ended Berbantuan Media Audio Visual Dan Motivasi Terhadap Kompetensi Pengetahuan Matematika. MIMBAR PGSD Undiksha, 5(2). https://doi.org/10.23887/jjpgsd.v5i2.11074

Wicaksono, A. G., Jumanto, \& Oka, I. (2020). Pengembangan media komik komsa materi rangka pada pembelajaran IPA di sekolah dasar. Premiere Educandum: Jurnal Pendidikan Dasar Dan Pembelajaran, 10(2), 215-226. https://doi.org/10.25273/pe.v10i2.6384

Yektyastuti, R., \& Ikhsan, J. (2016). Pengembangan Media Pembelajaran Berbasis Android pada Materi Kelarutan untuk Meningkatkan Performa Akademik Peserta Didik SMA. Jurnal Inovasi Pendidikan IPA, 2(1), 88-99. https://doi.org/10.21831/jipi.v2i1.10289

Yuniarni, D., Sari, R. P., \& Atiq, A. (2020). Pengembangan Multimedia Interaktif Video Senam Animasi Berbasis Budaya Khas Kalimantan Barat. Jurnal Obsesi : Jurnal Pendidikan Anak Usia Dini, 4(1), 290. https://doi.org/10.31004/obsesi.v4i1.331 